\title{
The Response of Consumption in Russian Households to Economic Shocks
}

\author{
By: Steven Stillman
}

William Davidson Working Paper Number 412

October 2001 


\title{
The Response of Consumption in Russian Households to Economic Shocks
}

\author{
Steven Stillman \\ RAND \\ Mail Stop M-15A \\ 1700 Main Street, P.O. Box 2138 \\ Santa Monica, CA 90407-2138 USA \\ Tel: 310-393-0411 ext. 7719 \\ Fax: 310-451-7061 \\ Email: stillman@rand.org
}

October 2001

\footnotetext{
* I would like to thank Shelly Lundberg, Dick Startz, Bob Schoeni, Steven Haider, Dan Berkowitz, and Duncan Thomas for helpful comments. I would especially like to thank Judy Thornton and Dan Berkowitz for collecting and providing to me various data series from Goskomstat. I gratefully acknowledge financial support from the National Institute on Child Health and Human Development.
} 


\begin{abstract}
This paper examines the extent to which consumption in Russian households responds to exogenous income shocks. During the time period studied in this paper (1994 - 1998), Russia experienced two major economic crises. Both featured extreme movements in the real ruble-dollar exchange rate. The price of oil, which is typically thought to have a strong effect on the Russian economy, was also quite volatile during this time period. This paper exploits these large changes in oil prices and exchange rates, as well as community-level variations in wage and pension arrears, to identify exogenous shocks to household income. Using representative panel data on urban households from the Russian Longitudinal Monitoring Survey, I find that a household which experiences an exogenous shock of $10 \%$ of its total income changes both its food and total non-durable expenditure by $7-11 \%$. Most evidence indicates that these shocks are transitory in nature and thus the traditional Life Cycle/Permanent Income Hypothesis model is firmly rejected as describing the behavior of Russian households. Additional results indicate that changes in household savings are negatively related to exogenous income shocks, with this relationship strongest for low wealth households. Only models of consumption which include precautionary savings motives can explain why poorer households both reduce their consumption and increase their savings in response to an exogenous decline in income.
\end{abstract}

Keywords: consumption, savings, consumption smoothing, precautionary savings, economic shocks, Russia

JEL-Code: D12, D91, O16, P36 


\section{Non-Technical Summary}

This paper examines the extent to which consumption in Russian households responds to exogenous income shocks. Households in transition economies face high levels of economic uncertainty, as the market infrastructure and economic institutions in these countries are often underdeveloped. Russia's economy, in particular, is highly dependent on price-volatile commodity exports (prominently, oil, gas, ferrous metals, aluminum, and timber). Many households in these countries lack access to formal credit and insurance markets, and thus may have difficulty smoothing consumption, especially against large aggregate shocks.

Between 1994 and 1998, Russia experienced two major crises with real GDP falling by around 15\% between the fall of 1994 and 1995 and 30\% between the fall of 1997 and 1998. Both crises featured extreme movements in the real dollar-ruble exchange rate. The price of oil, which is typically thought to have a strong effect on the Russian economy, was also quite volatile during this period. This paper exploits these large changes in oil prices and exchange rates to identify exogenous shocks to household income. Community-level data on fuel production and foreign trade are combined with time-series data on oil prices and exchange rates to develop instruments for exogenous income shocks which vary across both time and space. Likewise, community-level variations in wage and pension arrears are also used as instruments.

Using representative panel data on urban households from the Russian Longitudinal Monitoring Survey (RLMS), I find that a household which experiences an exogenous shock of $10 \%$ of its total income changes both its food and total non-durable expenditure by $7-11 \%$. Most evidence indicates that these shocks are transitory in nature and thus the 
traditional Life Cycle/Permanent Income Hypothesis model is firmly rejected as describing the behavior of Russian households. Additional results indicate that changes in household savings are negatively related to exogenous income shocks, with this relationship strongest for low wealth households. Only models of consumption which include precautionary savings motives can explain why poorer households both reduce their consumption and increase their savings in response to an exogenous decline in income.

These results indicate that exogenous economic shocks have large and significant effects on both food and total non-durable expenditure in urban Russian households. As sizeable negative shocks have been common during the transition period, large reductions in household expenditure may have had detrimental effects on nutrition and health, on school attendance, on the quality and quantity of care for the elderly, and on political stability. In developed countries, government transfer programs, such as unemployment insurance and welfare (general assistance), typically serve to protect vulnerable households from temporary reductions in income. The evidence in this paper advises that the Russian government should develop or improve these types of programs in order to reduce the negative effects of economic shocks on households. Other ways of accomplishing this goal would be to increase access to and stability in the financial sector and to continue privatizing both land and the housing stock. Each of these changes, by making savings more efficient and less costly, should reduce the precautionary savings motives of households and increase the likelihood that they smooth consumption. 


\section{I) Introduction}

This paper examines the extent to which consumption in Russian households responds to exogenous income shocks. Households in transition economies face high levels of economic uncertainty, as the market infrastructure and economic institutions in these countries are often underdeveloped. Russia's economy, in particular, is highly dependent on price-volatile commodity exports (prominently, oil, gas, ferrous metals, aluminum, and timber). Many households in these countries lack access to formal credit and insurance markets, and thus may have difficulty smoothing consumption, especially against large aggregate shocks.

Figure 1 displays Russia's seasonally adjusted real GDP, the real dollar spot price of European Brent crude oil, and the real dollar-ruble exchange rate from the fourth quarter of 1994 to the fourth quarter of 1998 (normalized to the fourth quarter of 1994). During this time period, Russia experienced two major crises with real GDP falling by around $15 \%$ between the fall of 1994 and 1995 and 30\% between the fall of 1997 and 1998. Both crises featured extreme movements in the real dollar-ruble exchange rate. The price of oil, which is typically thought to have a strong effect on the Russian economy, was also quite volatile during this period.

This paper exploits these large changes in oil prices and exchange rates to identify exogenous shocks to household income. Community-level data on fuel production and foreign trade are combined with time-series data on oil prices and exchange rates to develop instruments for exogenous income shocks which vary across both time and space. Likewise, community-

\footnotetext{
1 Quarterly data on nominal GDP are obtained from IMF International Financial Statistics Online (imf.largo.apdi.net). Daily data on the spot price of crude oil are obtained from the Energy Information Administration at the U.S. Department of Energy (www.eia.doe.gov/oil_gas/petroleum/info_glance/crudeoil.html). Biweekly data on the official nominal dollar-ruble exchange rate are obtained from the Central Bank of Russia (www.cbr.ru/eng/currency_base/dynamics.asp). Each series is appropriately deflated using monthly CPI data available from Goskomstat (The Russian Federation Statistical Agency - www.gks.ru/eng/) and the US Bureau of Labor Statistics (http://www.bls.gov/cpihome.htm), and is averaged over the appropriate time period. Russia's real
} 
level variations in wage and pension arrears are also used as instruments.

The analyses in this paper use representative panel data on urban households from the Russian Longitudinal Monitoring Survey (RLMS). This dataset contains detailed information on household income, expenditure, savings, and non-financial wealth. These data have many advantages over the data used in previous studies of household consumption behavior. For example, having independent measures of both expenditure and savings allows this paper to more comprehensively test hypotheses generated by different intertemporal consumption models than is done in previous work

To preview the results: I find that a household which experiences an exogenous shock of $10 \%$ of its total income changes both its food and total non-durable expenditure by $7-11 \%$. Most evidence indicates that these shocks are transitory in nature and thus the traditional Life Cycle/Permanent Income Hypothesis model is firmly rejected as describing the behavior of Russian households. Additional results indicate that changes in household savings are negatively related to exogenous income shocks, with this relationship strongest for low wealth households. Only models of consumption which include precautionary savings motives can explain why poorer households both reduce their consumption and increase their savings in response to an exogenous decline in income.

\section{II) Literature Review}

Evidence from both developed and developing countries indicates that households use a variety of mechanisms to reduce the impact that economic shocks have on consumption and on overall welfare. Alderman and Paxson (1994) and Deaton (1997, ch. 6) provide excellent surveys of the

GDP is seasonally adjusted by regressing the series on quarterly indicator variables. 
literature on consumption smoothing behavior. In many of these papers, the empirical work focuses on the estimating the Euler equation resulting from intertemporal utility maximization (for example, Hall and Mishkin 1982). As shown in the next section, deriving an estimable model using this approach requires very strong assumptions about household preferences, the income generating process, and liquidity constraints, and has been strongly critiqued in recent papers (for example, Carroll 2001). Another common approach taken in previous studies has been to directly instrument for permanent income (for example, Bhalla 1980). Instruments used have included assets, education, multiple-year averages of income, unemployment, and long-run averages of rainfall. These instruments are only valid if they are uncorrelated with the marginal utility of household consumption, which often appears hard to justify.

A handful of recent papers have turned to quasi-natural experiments in order to identify exogenous changes in income. As this is the approach taken in this paper, I will briefly summarize a few of these studies. Most have examined the response of household consumption to predictable changes in income. For example, Parker (1999) examines the effect of changes in social security taxes on consumption in the US and concludes that a $1 \%$ change in after-tax income causes non-durable expenditure to change by around .5\%. Souleles (1999) examines the effect of income tax refunds on consumption in the US and concludes that a similar size change in income causes non-durable expenditure to change by around .25\%. Paxson (1993) and Browning and Collado (2001) compare exogenous seasonal changes in income, caused by seasonal weather variation and by semi-annual wage bonuses, to changes in expenditure in Thailand and Spain, respectively. Both papers concluded that in each country the pattern of household non-durable expenditure does not depend on the seasonal pattern of income.

Browning and Crossley (2000) discuss these papers and other similar studies and conclude 
that bounded rationality appears to offer a reasonable explanation for these often contradictory results. When predictable income changes are small and variable, as in Parker and Souleles, households avoid calculating the optimal consumption response, but when they are large and occur year after year, as in Paxson and Browning and Collado, households respond appropriately and smooth their consumption. Examining the response of household consumption to generally unanticipated changes in income, as is done in this paper, provides an important counterpart to these studies. As the income shocks observed in Russia during the sample period are very large and arguably unexpected, actively avoiding consumption smoothing should have been very costly (in the sense of welfare loss). Thus, when discussing the results in this paper we should be able to rule out explanations that focus on bounded rationality.

Only two papers to my knowledge examine the effect of largely unanticipated exogenous changes in household income on consumption. Cochrane (1991), examines the effect of longterm illness, involuntary job loss, work lost due to strike, and involuntary move on consumption in the US. He finds that food consumption is responsive to long-term illness and involuntary job loss, but not to work lost due to strike and involuntary move. This paper is handicapped by the difficulty in identifying whether these shocks are transitory or permanent, to what extent they are anticipated, and whether they directly affect the marginal utility of consumption (which seems likely for illness). Paxson (1992) examines the effect of rainfall shocks on rural farm households in Thailand and concludes that a $10 \%$ change in transitory household income causes residual consumption (i.e. income minus savings) to change by $2-3 \%$. Unfortunately, it does not appear that Paxson's identification method has been used in other studies and thus it is impossible to know if these results are particular to farmers in Thailand or if they apply more generally. Also this approach is limited to the extent that it is, by definition, only applicable to rural areas. As 
many developing countries are becoming moderately urban and all transition economies are already, it is important to extend this type of identification method to non-farm households. This is the gap in the literature that this paper hopes to fill.

\section{III) Models Of Consumption ${ }^{2}$}

Consumers are assumed to solve the following standard intertemporal optimization problem:

$$
\begin{aligned}
& \max \mathrm{E}_{\mathrm{t}}\left[\sum_{i=t}^{T} \beta^{i-t} u\left(C_{i}\right)\right] \\
& \text { s.t. } \quad W_{t+1}=R\left(X_{t}-C_{t}\right)
\end{aligned}
$$

where $W_{t}$ is the stock of wealth at the beginning of period $t, X_{t}=W_{t}+Y_{t}$ is cash on hand in Deaton's (1991) terminology and equals wealth plus labor earnings $\left(Y_{t}\right), R=(1+r)$ where $r$ is the (constant) real interest rate, and $\beta=1 /(1+\delta)$ where $\delta$ is the (homogenous) discount rate. The utility function is assumed to be additively separable with identical subutility functions for each period. Unfortunately, as long as there is uncertainty about future labor income, even this pareddown model of consumption behavior cannot be solved analytically without making further simplifying assumptions. This can be seen by solving equation (1) for the case of iso-elastic subutility functions (i.e. $u\left(C_{t}\right) \equiv \frac{C_{t}^{1-\rho}}{1-\rho}$ ). If we assume that shocks to consumption are lognormally distributed, the approximate log-linearized Euler equation is

$$
\mathrm{E}_{\mathrm{t}}\left[\ln \left(C_{t+1} / C_{t}\right)\right] \approx \rho^{-1}(r-\delta)+(\rho / 2) \operatorname{var}_{t}\left[\ln \left(C_{t+1} / C_{t}\right)\right]
$$

The second term in this equation, which includes the conditional variance of consumption growth, is not analytically tractable. Two approaches for dealing with this problem have been

\footnotetext{
${ }^{2}$ This section draws heavily on Carroll (1997) and Deaton (1991).
} 
developed.

The traditional approach has been to assume that either there is no uncertainty about future labor income or that consumers have quadratic utility functions (and thus marginal utility is linear in consumption). In either case the second-order term in equation (2) is constant or zero and consumption growth follows a random walk. While both of these assumptions appear quite restrictive and unrealistic, this approach has inspired countless papers which test what I will call the 'traditional Life Cycle/Permanent Income Hypothesis model.' It is easy to show that the solution to this model implies that the optimal level of consumption is directly proportional to the sum of cash on hand and the discounted present value of the expected stream of future income. This generates the testable hypothesis that consumption should be much more responsive to permanent income shocks (i.e. shocks to both cash on hand and the expected stream of future income) than to transitory income shocks (i.e. shocks which only affect cash on hand). In the strictest version of this model, which adds the assumptions that households are infinite-lived and the discount rate equals the real interest rate, permanent shocks should be completely consumed and transitory shocks completely saved.

The second more recent approach has forsaken closed-form solutions. These papers typically start by demonstrating that precautionary savings appears to be an important empirical phenomena (i.e. most households hold savings for emergencies). More realistic intertemporal consumption models, which allow for precautionary motives, are then developed either by incorporating binding liquidity constraints (Deaton 1991) or by allowing consumers to be sufficiently impatient (Carroll 1997). These model are then calibrated to actual data and solved numerically. Two important regularities emerge. First, consumption is responsive to transitory 
income shocks, especially for households with low levels of cash on hand. Moderately impatient households (or those which are liquidity constrained), faced with uncertain future income, increase (decrease) consumption when receiving positive (negative) transitory income shocks because precautionary motives relax (strengthen) as cash on hand increases (decreases). Second, household engage in 'buffer-stock' savings behavior. Each household has a target level of cash on hand relative to permanent income such that if actual cash on hand is greater than the target level, wealth is reduced, while if cash on hand is below the target level, the household attempts to increase wealth. This implies that household savings can actually be negatively related to transitory income shocks for households with very low levels of cash on hand.

Given the volatile nature of the Russian economy and the general underdevelopment of its financial institutions, in my opinion, a realistic model of household consumption behavior in Russia must incorporate: (1) stochastic labor income, (2) precautionary savings motives, (3) liquidity constraints, (4) borrowing costs, and (5) aggregate uncertainty. One possible empirical approach which could be taken in this paper would be to develop a stylized model which includes these feature, calibrate it using both aggregate and household-level data on the Russian economy, and perhaps estimate it using simulated methods of moments and the data on hand.

Whether such a task is feasible is another question. Very little Russian economic data is available and much of what is collected is thought to be of low quality. Russia is also an extremely heterogeneous country. These challenges, especially the lack of data, would make it difficult to estimate key model parameters such as the coefficient of relative risk aversion, the discount rate, and the distribution of permanent income, even if they were restricted to being the same for the entire population. This paper instead takes an indirect approach, estimating

\footnotetext{
${ }^{3}$ More precisely, $1 /(1+\mathrm{r})$ percent of transitory shocks should be saved.
} 
reduced-form models of household consumption and savings, and then comparing the results from these models to those hypothesized by the different intertemporal consumption models. The development and calibration of a model specific to Russia is left to future work.

\section{IV) Empirical Methodology}

Adopting a reduced-form approach, household consumption is written as a linear function of household income and household characteristics which might affect the marginal utility of household consumption. As is typically the case, unobserved preferences are likely to play a large role in determining each household's level of consumption. Taking advantage of the available panel data, household-level fixed effects are included in the empirical model, which is equivalent to estimating the model in deviations from the within-household mean. This controls for time-invariant unobserved household-level heterogeneity in preferences, but at the cost of possibly exacerbating measurement error bias. The model is specified as,

$$
\ln \tilde{C}_{h t}=\gamma \ln \tilde{Y}_{h t}+\beta \tilde{X}_{h t}+\varepsilon_{h t}
$$

where $h$ indexes households, $t$ indexes time, $C_{h t}$ is a household's food or non-durable expenditure, $Y_{h t}$ is its total income, and $X_{h t}$ is a vector of household characteristics. ${ }^{-}$All variables (denoted with a tilde) are calculated as deviations from their within-household mean (i.e. $\tilde{Z}_{h t}=Z_{h t}-\sum_{i=t}^{T} Z_{h i} / T$ for any $\left.Z_{h t}\right)^{6}{ }^{6}$ The error term, $\varepsilon_{h t}$, is an idiosyncratic component which captures measurement error in within-household changes in consumption, time-varying

\footnotetext{
${ }^{4}$ Although individual income data is available for all household members, focusing on household behavior allows me to avoid modeling the distribution of resources within households and to concentrate on the important identification issues involved in estimating the household consumption model.

${ }^{5}$ This includes the number of male and female household members in the following age groups: <10, 10-17, 18-24, 25-29, 30-34, 35-39, 40-44, 45-49, 50-54, 55-59, 60+; and the number of male and female adults who are married, who have completed general secondary education, who have a specialized secondary, institute / university, and/or
} 
unobserved heterogeneity in preferences, and optimization errors, and is assumed to have mean zero and variance $\sigma_{\varepsilon}^{2}$.

It is not possible to interpret the coefficient on income in equation (3), $\gamma^{F E}$, as the average household's consumption response to an exogenous change in income. This coefficient is biased if either: (1) changes in household income are correlated with changes in household preferences for consumption (for example, events such as retirement, becoming a stay-at-home parent, or changing occupations are likely endogenously related to changes in consumption preferences), or (2) within-household changes in income are measured with error. The most promising approach for obtaining an unbiased estimate of the desired causal relationship is to identify an exogenous source of income variation and isolate the response of household consumption to a change in income caused by a change in this variable. This approach is ideal because instrumenting for household income eliminates both endogeneity and measurement error bias in the estimates (assuming one has appropriate instruments).

This paper uses four measures of exogenous economic shocks to instrument for household income in equation (3). ${ }^{\square}$ Two instruments are developed by combining community-level data on fuel production and foreign trade with time-series data on oil prices and exchange rates. These instruments are designed to allow the effect that a change in the oil price (exchange rate) has on household income to depend on how much fuel production (foreign trade) occurs in a particular community. It is assumed that changes in oil prices and exchange rates are caused by shocks to

professional course diploma

${ }^{6}$ Although technically incorrect, deviations from the mean are also referred to as changes in this paper.

7 The necessary identifying assumption is that these variables are correlated with household income but are uncorrelated with the residual in equation (3). In certain situations the joint null hypothesis that the model is properly specified and the instruments are uncorrelated with the residual can be tested using an overidentification test. Results from these tests are presented in section VI. 
aggregate demand and supply on world markets and thus are exogenous to Russian households. Community-level variations in wage and pension arrears are used as the other two instruments. Research by other authors has concluded that these arrears are caused by community and temporal variation in economic conditions and institutions and are largely independent of individual and household characteristics (Richter 2000; Lehmann et. al. 1999). ${ }^{\mathrm{g}}$ The first-stage equation of the fixed effects-instrumental variables (FE-IV) estimator is specified as:

$$
\ln \tilde{Y}_{h t}=\delta \operatorname{Shock}_{c t}+\theta \tilde{X}_{h t}+\mu_{h t} \text {, }
$$

where $c$ indexes communities, Shock $k_{c t}$ is one or all of the four measures of exogenous economic shocks, which are defined in greater detail in section VI, $\mu_{h t}$, is an idiosyncratic component which is assumed to have mean zero and variance $\sigma_{\mu}^{2}$, and all other variable are defined as above. This equation directly relates changes in household income to exogenous changes in economic conditions. The FE-IV estimator follows a very straightforward estimation procedure. Equation (4) is estimated and is then used to predict changes in household income using only the information on exogenous economic shocks (and changes in household characteristics). These predicted changes are then substituted into equation (3) for the actual changes. The resultant coefficient on income in this model, $\gamma^{F E-I V}$, can now be interpreted as the average household's consumption response to an exogenous change in household income..$^{-}$

\section{V) Data}

RLMS is a household-based representative survey of Russia collected by the Population Center

\footnotetext{
${ }^{8}$ Local governments in Russia are responsible for collecting taxes and pension contributions, and for distributing pensions and a significant portion of wages (directly to doctors, teachers, miners, Army personnel, and other state employees, and indirectly to other workers because of the prevalence of soft-budget constraints).

${ }^{9}$ The FE-IV estimator follows this exact two-step procedure, but also corrects the variance-covariance matrix of the
} 
at the University of North Carolina. All empirical work in this paper uses data from phase II of the survey, which covers the years 1994 - 1996 and 1998 (rounds 5 - 8). ${ }^{\square}$ RMS is longitudinal, but does not attempt to follow individuals or households who move from their original dwelling. However, each year, any new household in a dwelling previously occupied by a sample household is invited to join the survey, and many do. In all rounds, data are collected at the individual, household, and community level. ${ }^{-}$Overall, RLMS samples 4,380 households, providing a total of 11,838 observations, which contain at least one prime-age adult, defined as men aged 18 to 59 and women aged 18 to 54 (considered the normal working ages for Russian men and women).

All rural households are excluded from the analyses in this paper. This is done for two reasons. First, most rural households are strongly orientated towards farming, and thus the exogenous economic shocks examined in this paper have little effect on their income and my identification strategy is less promising. Second, RLMS contains limited data on household production. It is especially difficult to value the consumption of own-production, and consequently, for most households, income includes own-production while expenditure does not. Because both off-farm labor supply and the intensity of farming are endogenously determined with unobserved weather shocks and other unobservables there is no straightforward solution to this problem. As urban households make up $77 \%$ of the RLMS sample and the Russian population, this sample restriction should not diminish the relevancy of the results in this paper.

main equation to account for the first-step in the estimation process.

${ }^{10}$ The project description at www.cpc.unc.edu/rlms provides complete information about the RLMS survey and its sampling procedure. The phase II surveys are conducted in the late Fall of each year (in Nov. and Dec. of 1994 and 1998, and in Oct. and Nov. of 1995 and 1996).

${ }^{11}$ All individuals in each household are surveyed with the exception of some elderly and very young members. Extensive data is collected for each of the 159 survey sites. Information is provided to assign the 159 sites to 38 oblast (state) level primary sampling units (PSUs) and to 12 regions. 


\section{William Davidson Institute Working Paper 412}

Excluding rural households reduces the sample size to 3,524 households, providing 9,098 observations. All analyses in this paper focus on within-household changes in income and expenditure. Thus, it is necessary to drop 1,155 households (and observations) which are in RLMS for only one year. An additional 34 households and 169 observations are dropped because they have missing data on either expenditure or income. This leaves a total of 2,335 households, providing 7,774 observations, in the dataset used in all analyses in this paper.

The household respondent (typically, an older women in the household) is asked a comprehensive set of questions on income, expenditure, and savings. Having independent measures of both expenditure and savings is an important feature of the RLMS data as it allows this paper to more comprehensively test hypotheses generated by different intertemporal consumption models than is done in previous work. Total household income is based on the response to the following question: "And, concluding this part of our conversation, tell me, please, what was the monetary income of your entire family in the last 30 days? Include here all money received by all members of the family: wages, pensions, stipends, and other money received, including hard currency, but convert hard currency into rubles." Two measures of consumption are used. The first is a monthly measure of food expenditure based on a seven day recall of purchases of fifty-seven food items. The second is a monthly measure of total nondurable expenditure which sums expenditure on food, clothing, fuel, services, rent, and utilities. The measure of net savings used in this paper sums net flows into the following financial assets: (1) bank accounts, (2) loans, (3) insurance, and (4) stocks and bonds, and net purchases of durable goods (including TVs, VCRs, furniture, household appliances, cars, motorcycles, apartments, homes, and land, as well as similar items). Given the high levels of inflation and

\footnotetext{
${ }^{12} 1,264$ of these households provide four years of data, 576 provide three, and the remaining 495 provide two.
} 
unstable banking system in Russia, durable goods should be important for storing wealth.

Table 1 presents summary statistics for the main variables used in all analyses. ${ }^{1.3}$ The first column presents means and standard deviations for the main sample used throughout the paper. The second summarizes the same variables for all urban household in round 5 with at least one adult member. Because this is the initial year of the survey, these households provide a representative baseline sample to which the main sample can be compared. The third column presents the summary statistics for all urban households which are dropped from the main sample for the reasons noted above.

The distribution of most variable in the main sample are very similar to those for all households in round 5. Non-sample households are smaller, better educated, and perhaps betteroff in terms of income and expenditure than the households in the main sample. ${ }^{-1}$ Households who are more economically successful, and perhaps less vulnerable to economic shocks, may drop out of the survey because their time has become more valuable. If this is true, the results in this paper may be bias towards finding a greater consumption response than is actually occurring in Russian households. This is a valid concern and unfortunately without follow-up data on the non-sample households it is impossible to test whether this sample selection bias exists. Based on the similarity of the observables between the sample households and all households in round 5, my feeling is that this bias is likely to be small.

\footnotetext{
13 The variables used but not summarized include household membership by age group, by a few education levels, and gender interactions with all of the demographic variables. All nominal values are deflated using a chainweighted community-level Tornqvist price index (1998 Moscow City is the base community-year) which is calculated using the household expenditure and community price data available in RLMS. As discussed in Deaton and Muellbauer (1980), at a second-order approximation this is the true index for any arbitrary cost function. One advantage RLMS has over many other datasets for studying household consumption behavior is that the income, expenditure, and savings variables refer to the same monthly reference period, and thus the results in this paper are insensitive to the choice of price index.

${ }^{14}$ These findings match those in Heeringa (1997), which examines attrition in RLMS and discusses its overall
} 


\section{William Davidson Institute Working Paper 412}

Table 2 summarizes household expenditure, income, and savings by source for each survey year. Average total household income declined by around 25\% between 1996 and 1998 . The 1998 crisis lead to a large decline in labor income (24\%), government transfers (15\%), and interhousehold transfers (46\%). During the same time period, average household non-durable expenditure declined by $26 \%$. This decline was spread fairly evenly across expenditure components, with food expenditure falling by $27 \%$, clothing expenditure by $16 \%$, services by $26 \%$, and fuel expenditure by $36 \%$. A similar pattern emerges when examining the smaller 1994 crisis.

Figure 2 displays the average level of household non-durable expenditure (the dashed line) and total household income (the solid line) in each community (sites within the same PSU are aggregated together and will hereafter be referred to as communities) for each year. ${ }^{\square}$ The extent to which average household expenditure co-moves with income is striking. In twenty-four (eighteen) out of the thirty-three communities the correlation coefficient between these two series is greater than $.7(.9)$. This co-movement occurs in communities that have very different time-profiles of average income and consumption.

Taken together this aggregate evidence suggests that exogenous changes in income have large effects on consumption in Russian households. However, it is important to extend this analysis to the household-level. This evidence might be misleading, as various endogenous factors may be causing households to simultaneously reduce both their income and expenditure. For example, increased preferences for leisure may lead simultaneously to lower incomes and to reductions in expenditure by increasing retirement or reducing female labor force participation.

\footnotetext{
representiveness.

${ }^{15}$ There are 33 urban communities in RLMS representing 30 out of 89 oblasts in Russia. The average community
} 


\section{VI) Main Results}

As discussed in section IV, this paper utilizes four measures of exogenous economic shocks to instrument for household income in the reduced-form consumption model: (1) the log real dollar spot price of European Brent crude oil in each year interacted with the amount of fuel production as a percentage of total industrial production in each community in 1998, (2) the log real rubledollar exchange rate in each year interacted with the log dollar value of total trade (imports plus exports) ${ }^{16}$ per capita outside the Commonwealth of Independent States ${ }^{11}$ in each community in 1998 , (3) the average percentage of monthly earnings owed to workers in each community-year, and (4) the average log real value of pensions paid to all elderly in each community-year. ${ }^{\mathrm{L}}$

Table 3 displays the variation across communities and years in each of these variables (actually the linear equivalents of all log variables). As can be seen in panel A, each measure has considerable variation across years, with oil prices fluctuating between 10 and 17 dollars per barrel, exchange rates between 12 and 24 rubles per dollar, owed wages between 20 and 36 percent of monthly earnings, and elderly pensions between 535 and 740 rubles. Each also follows a different pattern over time suggesting that they all contain some independent information on economic conditions. There is also considerable variation across communities with the interquartile range for fuel production in $1998, .1-14.6$ percent of total production, for

\footnotetext{
has 69 surveyed households per year with the smallest having 21 and the largest 212.

${ }^{16}$ I also experimented with more complicated interactions with separate measures of imports and exports. This did not have an appreciable effect on the results.

${ }^{17}$ The former Soviet Union minus the Baltic States.

${ }^{18}$ The source and calculation of the oil price and exchange rate variables are discussed in footnote \#1. These variables are averaged over the 30 days prior to each household interview, and thus, due to different interview dates, vary across households within the same year. However, this variation is quite small compared to the across-year variation in these variables and proves to be a very weak source of identification. The community fuel production and trade data are obtained from the 1998 Goskomstat regional yearbook. While one would ideally like to use data from before the survey period to avoid possible endogeneity problems, these appear to be unavailable. Data from the RLMS individual surveys are used to calculate the wage and pension arrear variables. The average community has 91 (46) adult workers (elderly) per year with the smallest having 18 (6) and the largest 309 (147). More details
} 
trade per capita in $1998, .13-.57$ dollars, for owed wages in the average year, $19-35$ percent of monthly earnings, and for elderly pensions in the average year, $550-645$ rubles.

Table 4 presents the results from estimating equation (4), the first-stage equation of the FEIV estimator. The dependent variable in each regression is log total household income. In panels A-D, each measure of exogenous economic shocks is separately included as an independent variable, while in panel $\mathrm{E}$ all are used in the same regression. Only the coefficients on these variables are presented along with their standard errors. ${ }^{10}$ Each regression also includes household fixed effects and all of the household characteristics noted in section IV. In the second column of each panel, year fixed effects are also included in each regression. These control for nationwide aggregate trends in income and consumption, which may reflect permanent changes in household preferences. They also absorb the time-series variation in oil prices and exchange rates, and it is now only possible to identify the interaction effects in these regressions. ${ }_{0}$ In the third column of each panel, region-year fixed effects, as well as year fixed effects, are added to each regression. These control for aggregate trends in income and consumption which differ by region. It is still only possible to identify the interaction effects in the oil price and exchange rate regressions and now all inference in these models is based on within-region differences in community fuel production or trade.

The coefficient of .175 in the first column of panel A, indicates that a $10 \%$ decrease (increase) in the world price of oil leads to a $1.8 \%$ decrease (increase) in income for the average

\footnotetext{
on the construction of these variables is available from the author by request.

${ }^{19}$ The complete results for all regression models in this paper are available from the author by request.

${ }^{20}$ The main effects are still weakly identified by the within-year variation in the timing of the household interviews, as discussed in footnote 18. Thus, they are still included in the regression models, but are left out of the tables and from the joint significance and overidentification tests of the instruments because multicollinearity with the year fixed effects makes it difficult to interpreting the coefficients.
} 


\section{William Davidson Institute Working Paper 412}

household in a community with no fuel production. As expected, oil price shocks are found to have larger effects on household income in communities with more fuel production. The second coefficient of .396 in this column and panel, indicates that the response of household income to oil price shocks is $4 \%$ greater for each $10 \%$ increase in fuel production in a community (i.e. a $10 \%$ change in the price of oil leads to a $5.7 \%(9.7 \%)$ change in household income for the average household in a community with $10 \%$ (20\%) fuel production). The addition of year fixed effects in column 2 has almost no effect on the results. The further addition of region-year fixed effects in column 3 reverses the sign on the interaction term, although it is no longer significantly different from zero. As the control variables in this specification remove most of the variation in oil price shocks, this result is not particularly surprising. The main effect and the interaction term are jointly significant at the $1 \%$ level in column 1 and the interaction term is significant at the 5\% level in column 2. This indicates that changes in oil prices are good instruments for changes in household income except when region-year fixed effects are included in the model.

Panel B presents similar results using changes in the ruble-dollar exchange rate to measure exogenous economic shocks. In the long-run, currency depreciation should lead to increased demand for Russian exports because of their lower price and to increased at-home substitution towards Russian-made goods because of the higher price of imported goods. On the other hand, in the short-run, depreciation reduces the amount of hard currency earned by exports. The results suggest that this type of short-run effect predominates, with a $10 \%$ depreciation (appreciation) leading to a $1.5 \%$ reduction (increase) in income for households in communities with no trade and for each $10 \%$ increase in community trade leading to an additional $1.1 \%$ reduction (increase). Similar results are found when year fixed effects, and both year and regionyear fixed effects are added to the regression model. The main effect and the interaction term are 
jointly significant at the $1 \%$ level in column 1 and the interaction term is significant at the $1 \%$ level in column 2 and the $10 \%$ level in column 3. This indicates that changes in exchange rates are also reasonable instruments for changes in household income in each model specification.

Panels C and D repeat these regression using changes in owed wages and elderly pensions to measure exogenous economic shocks. A $10 \%$ increase (decrease) in the percentage of wages owed in a community is estimated to lead to a $9.5 \%$ decrease (increase) in household income. Similar, although slightly larger, elasticities are found when adding year fixed effects and both year and region-year fixed effects. In each case the coefficient on owed wages is significantly different from zero at the $1 \%$ level. Likewise, a $10 \%$ increase (decrease) in elderly pension payments in a community is estimated to lead to a $0.7 \%$ increase (decrease) in household income. Again, similar although slightly larger, elasticities are found when adding year fixed effects and both year and region-year fixed effects, and in each case the coefficient on elderly pensions is significantly different from zero at the $1 \%$ level. Both of these measures of economic shocks appear to be strong instruments for changes in household income.

In panel $\mathrm{E}$, all of the measures of exogenous economic shocks are jointly included in each regression. Besides exchange rate shocks, each measure has a significant effect on household income, indicating that each contains some independent information on economic conditions. The coefficients on all of the economic shock variables, besides exchange rates, are of the same sign and similar magnitude as those in panels A-D and, in each specification, the economic shock variables are jointly significant at the $1 \%$ level. When all of the shocks are simultaneously used as instruments the results have greater precision, so it is very encouraging that together they are strong predictors of changes in household income.

Table 5 presents the results from estimating equation (3) using each of the four measures of 
exogenous economic shocks (and all four measures together) to instrument for household income. In the first row of each panel, the dependent variable in each regression is log food expenditure, in the second, log non-durable expenditure. Only the coefficient on household income in each regression, $\gamma^{F E-I V}$, is presented along with its standard error. Each regression also includes household fixed effects and all of the household characteristics noted in section IV. In the second column of each panel, year fixed effects are also included in each regression, in the third, region-year fixed effects, as well as year fixed effects.

Panel A presents the results from estimating equation (3) without instrumenting for household income. A $10 \%$ change in household income appears to have around a $2 \%$ effect on household consumption. However, as previously discussed, this coefficient is biased if either: (1) changes in household income are correlated with changes in household preferences for consumption, or (2) within-household changes in income are measured with error. Panels B-F repeat panel A using each measure of exogenous economic shocks to instrument for household income. The results in these panels are extremely different, which suggests that the estimates in panel A are biased. More formally, an augmented regression test is used to determine whether household income is endogenous in equation (3). In each model, the exogeneity of household income is rejected at the $1 \%$ level.

The results in panels $\mathrm{B}-\mathrm{F}$ indicate that a $10 \%$ change in income, caused by exogenous economic shocks, leads to a 9-15\% change in consumption for the average Russian household. Adding year fixed effects in column 2 leads to a small reduction in the estimated elasticities, with a $10 \%$ exogenous change in income causing a $7-11 \%$ change in consumption for the

${ }^{21}$ All regression models is this table are also run in first-differences, instead of including household fixed effects. 
average household. These are consider the preferred results, as the evidence on hand suggests that these models are well identified, and these results are robust to nationwide aggregate trends in income and consumption, which may reflect permanent changes in household preferences. Adding year and region-year fixed effects in column 3 has little effect on the results (elasticities range from .7-1.5), although they are less precisely estimated. As noted above, the additional control variables in this specification remove a good deal of the variation in the instruments, which weakens the identification power of these models.

All the estimates of $\gamma^{F E-I V}$ are significantly different from zero at the 5\% level. Similar results are found for both food expenditure and non-durable expenditure and when using each of the different measures of economic shocks as instruments. The joint null hypothesis that the model is properly specified and the instruments are valid instruments can be tested using an overidentification test in each regression model that has multiple instruments. This null hypothesis cannot be rejected in column 1 for oil price shocks, but is strongly rejected for exchange rate shocks and for all four measures of economic shocks together. In the preferred specification in column 2 , and in column 3 , an overidentification test fails to reject the null hypothesis in each applicable model. As overidentification tests are sensitive to minor model misspecifications, these results provide strong support for the validity of the instruments used in this paper.

\section{VIII) Discussion}

The main results indicate that exogenous shocks to household income, caused by changes in oil prices, exchange rates, wage arrears, and/or pension payments, have large and significant effects

All results are qualitatively unaffected, although the estimates are less precise. 
on both food and total non-durable expenditure. In order to compare these results to those hypothesized by different theoretical model of intertemporal household consumption behavior, we need additional information. The first necessary step is to evaluate whether these shocks are transitory or permanent. Two approaches are taken to answering this question.

First, monthly data on the oil price and exchange rate variables, which are available from September 1994 until June 2001, are directly analyzed to determine their time-series properties. ${ }^{2}$ A Kwiatkowski, Phillips, Schmidt, Shin (KPSS) test for stationarity is run on these variables. I fail to reject stationarity of the oil price and stationarity of the exchange rate is only rejected at the $10 \%$ level. $^{\text {a }}$ Akaike's Information Criterion (AIC) and Schwarz's Criterion (SIC) are then used to assess the goodness of fit of various ARMA models for changes in the oil price and exchange rate, calculated as deviations from their overall mean. Oil price deviations are best fitted to an $\mathrm{AR}(1)$ process with a coefficient of .943 and exchange rate deviations to an $\operatorname{ARMA}(1,1)$ with coefficients .957 and .424 . Shocks to both variables appear to be highly persistent, with $49 \%$ (59\%) of an oil price (exchange rate) shock still present one year later.

Next, a more indirect approach is taken by augmenting the models already estimated in this paper. The response of household consumption between round $t-1$ and to changes in all of the economic shock variables between round $\mathrm{t}-1$ and $\mathrm{t}$ and between round $\mathrm{t}-2$ and $\mathrm{t}-1$ is estimated. Also included as independent variables are changes in household characteristics between round t1 and $t$ and year fixed effects. The results from these models are summarized, but are not presented, as the individual coefficients are difficult to interpret. Contemporaneous changes in

\footnotetext{
${ }^{22}$ Unfortunately, only the short time-series from RLMS is available for the wage and pension arrears variables, so these are excluded from this analysis.

${ }^{23}$ The exchange rate series appears to have two structural breaks (crisis depreciations in 1994 and 1998) so this test, as well as inference from simple time-series models, may not be appropriate.
} 
economic shocks are found to jointly have a strong significant effect on changes in both food and non-durable expenditure, while past changes in economic shocks are found to have no effect.

Likewise, table 6 presents, in panel A, estimates of the response of household consumption between round $\mathrm{t}-1$ and to exogenous changes in household income between round $\mathrm{t}-1$ and $\mathrm{t}$ and between round $\mathrm{t}-2$ and $\mathrm{t}-1$. Also included as independent variables are changes in household characteristics between round $\mathrm{t}-1$ and $\mathrm{t}$ and year fixed effects. All changes in household income are instrumented with contemporaneous changes in economic shocks. In panel B, an identical model is estimating with changes in household income between round $\mathrm{t}-1$ and $\mathrm{t}$ replaced by changes in income between round $t$ and $t+1$. In each regression, contemporaneous exogenous changes in income have large significant effects on consumption, while past or future changes have no effect.

Most of the above evidence indicates that the economic shocks used as instruments in this paper are transitory in nature. If they were permanent, past changes in the shocks, and past change in income caused by changes in the shocks, should have had an effect on current period changes in consumption. While the direct time-series evidence on oil prices and exchange rates suggests that changes in these variables are fairly persistent, the indirect evidence provides a compelling counter-argument. Given this evidence, the traditional Life Cycle/Permanent Income Hypothesis (LC/PIH) model is firmly rejected as describing the behavior of Russian households. As a $10 \%$ exogenous change in income is found to cause a $7-11 \%$ change in consumption for the average household, income shocks would have to be almost entirely permanent in order for these results to be rationalized by the traditional LC/PIH model.

Another way to test the traditional LC/PIH model is to examine whether current savings predicts future changes in income. For example, if a household knows that one of its working 
members is likely to loss their job in the next year or is planning to retire, they should increase their savings in the current year to properly smooth consumption. Table 7 presents, in panel A, estimates of the effect of current net savings on changes in household income between round $t$ and $t+1$ (or between round $t+1$ and $t+2$ ). Also included as independent variables are current household characteristics and year fixed effects. In panel B, changes in net savings and in household characteristics between round $\mathrm{t}-1$ and $\mathrm{t}$, and year fixed effects, are used as the independent variables in each regression. Contrary to what is hypothesized by the traditional LC/PIH model, current savings and changes in savings are found to have a positive effect (no effect) on changes in income between rounds $t$ and $t+1(t+1$ and $t+2)$. These results suggest that, as opposed to serving as a mechanism for smoothing consumption, household savings in Russia may allow households to better protect or to increase their future income. This could occur if increased savings (i.e. a larger 'buffer-stock') encourages households to make riskier investment (financial and human capital) decisions.

Given the rejection of the traditional LC/PIH model, I now access the ability of intertemporal consumption models which include precautionary savings motives to explain the consumption behavior of Russia households. As discussed in section III, the response of both household consumption and savings to exogenous transitory changes in income will depend on household wealth in models which include precautionary savings. In these models, positive (negative) transitory income shocks have positive (negative) effects on consumption and can have negative (positive) effects on savings, especially for households with low levels of wealth.

The best proxy for wealth available in RLMS are data collected on non-financial assets. ${ }^{24}$

\footnotetext{
${ }^{24}$ The value of household non-financial assets is the total estimated worth of the following assets: (1) Refrigerator; (2) Separate Freezer; (3) Washing Machine; (4) Black and White TV; (5) Color TV; (6) VCR; (7) Car or Truck; (8)
} 
Table 8 presents the results from estimating the response of consumption and savings to exogenous changes in income, interacting changes in household income with indicators variables for three equal-sized groups based on each household's non-financial assets in its first year in RLMS. ${ }^{-5}$ The model is otherwise identical to the second column of panel $\mathrm{F}$ in table 5 (i.e. all economic shocks are used as instruments for household income and year fixed effects are included in the regressions). ${ }^{6}$ The response of household consumption to exogenous income shocks does not appear to depend on household wealth, as the interaction terms in these models are not significantly different from zero. Household savings is found to be negatively related to exogenous changes in income (although only significant at the $11 \%$ level). While the interaction terms are imprecisely estimated, this effect appears to be strongest for the low wealth households. These are not consistent findings. If the response of consumption to income shocks is unrelated to household wealth than so should the response of savings. In each model, an overidentification test rejects at the $1 \%$ level the joint null hypothesis that the model is properly specified and the instruments are valid instruments. However, when exchange rate shocks are removed from the regression, the null hypothesis is no longer rejected for either consumption regression, although it is still rejected for the savings regression.

These results are somewhat consistent with those hypothesized by intertemporal consumption models which include precautionary motives. The combined evidence that transitory income shocks have around a one-to-one relationship with consumption and a negative relationship with savings can be explained by these models. However, the evidence that the

Motorcycle or Motorboat; (9) Tractor; (10) Garden Cottage; (11) Dacha (vacation home) or Other House; and (12) Other Apartment. More information is available from the author by request.

${ }^{25}$ First year assets are used to divide the sample because subsequent changes in assets may be correlated with both past and current economic shocks. All first year observations are also dropped from these regressions. 
response of household consumption to exogenous income shocks does not depend on household wealth is in conflict with the hypothesized results. One possible explanation for this finding is that aggregate uncertainty is so severe in Russia that even wealthier households exhibit `bufferstock' savings behavior.

\section{IX) Conclusions}

The results in this paper indicate that exogenous economic shocks have large and significant effects on both food and total non-durable expenditure in urban Russian households. As sizeable negative shocks have been common during the transition period, large reductions in household expenditure may have had detrimental effects on nutrition and health, on school attendance, on the quality and quantity of care for the elderly, and on political stability. In developed countries, government transfer programs, such as unemployment insurance and welfare (general assistance), typically serve to protect vulnerable households from temporary reductions in income. The evidence in this paper advises that the Russian government should develop or improve these types of programs in order to reduce the negative effects of economic shocks on households. Other ways of accomplishing this goal would be to increase access to and stability in the financial sector and to continue privatizing both land and the housing stock. Each of these changes, by making savings more efficient and less costly, should reduce the precautionary savings motives of households and increase the likelihood that they smooth consumption.

This paper is an important first step in our understanding of how economic shocks affect Russian households, however, in many ways it only examines the tip of the iceberg. It focuses on household expenditure, which in Russia may be a poor proxy for household well-being. If

\footnotetext{
${ }^{26}$ As net savings is a linear dependent variable, household income is entered linearly in this model.
} 
households substitute towards cheaper but more nutritious goods or if they replace expenditure with home production, declines in expenditure may not affect well-being. Future research can build upon the work in this paper by examining how economic shocks affect individual health and nutrition. This paper also focuses only on aggregate shocks. Household level shocks caused by events such as job loss or illness may also have serious consequences for household welfare. However, it may also be easier for households to smooth these more idiosyncratic shocks. Skoufias (2001), uses RLMS to examine the effect of individual level shocks, such as wage arrears, forced leave, and unemployment, on consumption, and is one of the few papers on consumption smoothing to utilize data from a transition economy. More research in this area is definitely needed. Finally, in line with the literature on household decision-making (Lundberg and Pollak 1996), future research would ideally extended the analysis in this paper to examine the effect of economic shocks on the within-household distribution of resources. 
William Davidson Institute Working Paper 412

\section{References}

Alderman, Harold and Christina Paxson. 1994. "Do the Poor Insure? A Synthesis of the Literature on Risk and Consumption in Developing Countries." in Bacha (ed.) Economics in a Changing World: Volume 4: Development, Trade, and the Environment. London: Macmillan Press.

Bhalla, Surjit. 1980. “The Measurement of Permanent Income and Its Application to Savings Behavior.” Journal of Political Economy 88. no. 4: 722-44.

Browning, Martin and M. Dolores Collado. 2001. "The Response of Expenditures to Anticipated Income Changes: Panel Data Estimates.” American Economic Review 91 (June). no. 3: 68192.

and Thomas F. Crossley. 2001. "The Life Cycle Model of Consumption and Savings." Journal of Economic Perspectives 15 (Summer). no. 3: 3-22.

Carroll, Christopher. 2001. "A Theory of the Consumption Function, With and Without Liquidity Constraints (Expanded Version).” NBER Working Paper 8387 (July).

. 1997. "Buffer-Stock Savings and the Life Cycle / Permanent Income Hypothesis." Quarterly Journal of Economics 62. no. 1: 1-56.

Cochrane, John. 1991. "A Simple Test of Consumption Insurance." Journal of Political Economy 99. no. 5: 957-76.

Deaton, Angus. 1997. The Analysis of Household Surveys. Baltimore: The Johns Hopkins University Press. . 1991. "Savings and Liquidity Constraints.” Econometrica 59 (September). no. 5: 1221-

48. and John Muellbauer. 1980. Economics and Consumer Behavior. Cambridge: Cambridge University Press. 
William Davidson Institute Working Paper 412

Hall, Robert E. and Frederic Mishkin. 1982. "The Sensitivity of Consumption to Transitory Income: Estimates from Panel Data on Households." Econometrica 50 (March). no. 2: 46182.

Heeringa, Steven G. 1997. "Russia Longitudinal Monitoring Survey Sample Attrition, Replenishment, and Weighting: Rounds V-VII.” University of Michigan Institute for Social Research (March).

Lehmann, Hartmut, Jonathan Wadsworth, and Alessandro Acquisti. 1999. "Grime and Punishment: Job Insecurity and Wage Arrears in the Russian Federation." Journal of Comparative Economics 27 (December). no. 4: 595-617.

Lundberg, Shelly and Robert A. Pollak. 1996. "Bargaining and Distribution in Marriage." Journal of Economic Perspectives 10 (Fall). no. 4: 139-58.

Parker, Jonathan A. 1999. "The Response of Household Consumption to Predictable Changes in Social Security Taxes.” American Economic Review 89 (September). no. 4: 959-73.

Paxson, Christina. 1993. "Consumption and Income Seasonality in Thailand." Journal of Political Economy 101 (February). no. 1: 39-72. 1992. "Using Weather Variability to Estimate the Response of Savings to Transitory Income in Thailand." American Economic Review 82 (March). no. 1: 15-33.

Richter, Kaspar. 2000. “Government Cash Transfers, Household Consumption, and Poverty Alleviation - The Case of Russia." CEPR Discussion Paper 2422 (April).

Skoufias, Emmanuel. 2001. "Consumption Smoothing in Russia: Evidence from the RLMS." draft. International Food Policy Research Institute (April).

Souleles, Nicholas. 1999. "The Response of Household Consumption to Income Tax Refunds." American Economic Review 89 (September). no. 4: 947-58. 


\section{William Davidson Institute Working Paper 412}

Table 1: Summary Statistics

\begin{tabular}{|c|c|c|c|}
\hline Mean (Standard Deviation) & Main Sample & Round 5 & Non-Sample \\
\hline \multirow[t]{2}{*}{ Household Non-Durable Expenditure } & 3,134 & 3,512 & 3,329 \\
\hline & $(2,908)$ & $(3,071)$ & $(3,326)$ \\
\hline \multirow[t]{2}{*}{ Household Food Expenditure } & 2,115 & 2,484 & 2,125 \\
\hline & $(1,807)$ & $(2,044)$ & $(1,840)$ \\
\hline \multirow[t]{2}{*}{ Total Household Income } & 2,854 & 3,314 & 2,985 \\
\hline & $(3,867)$ & $(4,620)$ & $(4,483)$ \\
\hline \multirow[t]{2}{*}{ Household Labor Income } & 1,790 & 1,877 & 1,858 \\
\hline & $(2,260)$ & $(2,230)$ & $(2,404)$ \\
\hline \multirow[t]{2}{*}{ Household Farm Income } & 0 & -10 & -4 \\
\hline & (394) & $(410)$ & (185) \\
\hline \multirow[t]{2}{*}{ Net Financial Savings } & -352 & -231 & -190 \\
\hline & $(3,240)$ & $(3,545)$ & $(3,189)$ \\
\hline \multirow[t]{2}{*}{ Net Savings (Financial and Durable Goods) } & 5 & 285 & 397 \\
\hline & $(3,811)$ & $(4,703)$ & $(5,321)$ \\
\hline \multirow[t]{2}{*}{ Non-Financial Assets } & 47,166 & 44,798 & 47,292 \\
\hline & $(68,974)$ & $(67,898)$ & $(70,579)$ \\
\hline \multirow[t]{2}{*}{ \# Household Members } & 3.50 & 3.59 & 2.97 \\
\hline & $(1.38)$ & $(1.44)$ & $(1.29)$ \\
\hline \multirow[t]{2}{*}{ \# Adults (M: 18-59, F: 18-54) } & 2.13 & 2.16 & 1.94 \\
\hline & $(0.90)$ & $(0.92)$ & $(0.77)$ \\
\hline \multirow[t]{2}{*}{ \# Children } & 0.97 & 1.02 & 0.79 \\
\hline & $(0.92)$ & $(0.95)$ & $(0.83)$ \\
\hline \multirow[t]{2}{*}{ \# Elderly } & 0.40 & 0.40 & 0.24 \\
\hline & $(0.65)$ & $(0.64)$ & $(0.52)$ \\
\hline \multirow[t]{2}{*}{ \# Male Household Members } & 1.64 & 1.69 & 1.40 \\
\hline & $(0.94)$ & $(0.95)$ & $(0.84)$ \\
\hline \multirow{2}{*}{ \# Married Adults } & 1.54 & 1.57 & 1.42 \\
\hline & $(1.02)$ & (1.04) & $(0.99)$ \\
\hline \# Completed General Secondary Education & 1.48 & 1.45 & 1.45 \\
\hline (normal academic standard: US high school) & $(0.93)$ & $(0.94)$ & $(0.87)$ \\
\hline \multirow{2}{*}{ \# With Institute / University Diploma } & 0.45 & 0.48 & 0.51 \\
\hline & $(0.71)$ & $(0.74)$ & $(0.72)$ \\
\hline Year is 1994 & $25 \%$ & $100 \%$ & $37 \%$ \\
\hline Year is 1995 & $27 \%$ & $0 \%$ & $14 \%$ \\
\hline Year is 1996 & $26 \%$ & $0 \%$ & $15 \%$ \\
\hline Year is 1998 & $23 \%$ & $0 \%$ & $34 \%$ \\
\hline Lives in Capital or Oblast Center (state capital) & $53 \%$ & $56 \%$ & $61 \%$ \\
\hline Lives in Raion Center (major town) & $42 \%$ & $37 \%$ & $35 \%$ \\
\hline Lives in Other Community & $5 \%$ & $7 \%$ & $5 \%$ \\
\hline Region is Moscow City & $8 \%$ & $9 \%$ & $8 \%$ \\
\hline Region is Northwest (includes St. Petersburg) & $5 \%$ & $6 \%$ & $8 \%$ \\
\hline Region is North & $7 \%$ & $6 \%$ & $5 \%$ \\
\hline Region is Central & $15 \%$ & $14 \%$ & $13 \%$ \\
\hline Region is Central Black-Earth & $6 \%$ & $5 \%$ & $5 \%$ \\
\hline Region is Volga-Vaytski & $5 \%$ & $5 \%$ & $4 \%$ \\
\hline Region is Volga & $13 \%$ & $11 \%$ & $8 \%$ \\
\hline Region is North Caucasia & $8 \%$ & $9 \%$ & $9 \%$ \\
\hline Region is Ural & $16 \%$ & $15 \%$ & $14 \%$ \\
\hline Region is West Siberia & $10 \%$ & $9 \%$ & $9 \%$ \\
\hline Region is East Siberia & $5 \%$ & $5 \%$ & $7 \%$ \\
\hline Region is Far East & $3 \%$ & $4 \%$ & $8 \%$ \\
\hline \# Observations & 7,774 & 2,429 & 1,324 \\
\hline
\end{tabular}

Note: All values are in real 1998 Moscow City rubles (1 USD $\cong 17$ real rubles) and are for the month previous the survey. 


\section{William Davidson Institute Working Paper 412}

Table 2: Household Expenditure, Income, and Savings By Source and Year

\begin{tabular}{lcccc}
\hline Mean (Standard Deviation) & 1994 & 1995 & 1996 & 1998 \\
\hline (A) Household Non-Durable Expenditure & 3,484 & 3,291 & 3,257 & 2,422 \\
(i) Food Expenditure & $(2,983)$ & $(2,875)$ & $(3,132)$ & $(2,442)$ \\
& 2,492 & 2,281 & 2,092 & 1,530 \\
(ii) Clothing Expenditure & $(2,039)$ & $(1,883)$ & $(1,690)$ & $(1,379)$ \\
& 396 & 367 & 408 & 341 \\
(iii) Services & $(726)$ & $(687)$ & $(792)$ & $(761)$ \\
& 512 & 538 & 658 & 488 \\
(iv) Fuel Expenditure & $(1,134)$ & $(1,140)$ & $(1,529)$ & $(1,052)$ \\
& 72 & 100 & 90 & 58 \\
(B) Total Household Income & $(266)$ & $(324)$ & $(286)$ & $(217)$ \\
& 3,257 & 2,848 & 2,994 & 2,258 \\
(i) Labor Income & $(4,359)$ & $(3,668)$ & $(3,959)$ & $(3,304)$ \\
& 1,847 & 1,848 & 1,946 & 1,480 \\
(ii) Government Transfers & $(2,163)$ & $(2,309)$ & $(2,546)$ & $(1,907)$ \\
& 446 & 401 & 428 & 363 \\
(iii) Net Interhousehold Transfers Received & $(590)$ & $(527)$ & $(637)$ & $(505)$ \\
& 120 & 85 & 123 & 67 \\
(iv) Farm Income & $(1,030)$ & $(997)$ & $(1,161)$ & $(806)$ \\
& -10 & -15 & 3 & 24 \\
(v) Miscellaneous Income & $(443)$ & $(312)$ & $(333)$ & $(476)$ \\
& 71 & 34 & 49 & 43 \\
(C) Net Savings (Financial and Durable Good) & $(486)$ & $(278)$ & $(368)$ & $(294)$ \\
& $(4,538)$ & $(3,547)$ & -83 & -40 \\
(i) Net Financial Savings & -270 & -381 & -434 & $(3,259)$ \\
& $(3,595)$ & $(3,188)$ & $(3,231)$ & $(2,875)$ \\
(ii) Net Durable Good Expenditure & 482 & 283 & 352 & 210 \\
& $(3,261)$ & $(2,711)$ & $(2,528)$ & $(2,173)$ \\
\hline (D) Non-Financial Assets & 44,464 & 45,812 & 47,570 & 51,271 \\
& $(67,445)$ & $(69,202)$ & $(67,635)$ & $(71,690)$ \\
\hline \# Observations & 1,938 & 2,067 & 2,009 & 1,760 \\
\hline
\end{tabular}

Note: All values are in real 1998 Moscow City rubles (1 USD $\cong 17$ real rubles) and are for the month previous the survey. Total household income is surveyed directly, and thus is not equal to the total of the five income components. Similarly, net financial savings is surveyed directly and is not equal to total income minus total consumption. Net financial savings includes nets flows into (1) bank accounts, (2) loans, (3) insurance, and (4) stocks and bonds for each household. 


\section{William Davidson Institute Working Paper 412}

Table 3: The Distribution of Economic Shocks Across Communities and Years

\begin{tabular}{|c|c|c|c|c|c|}
\hline $\begin{array}{l}\text { A) The Distribution of Economic Shocks } \\
\text { Across Years }\end{array}$ & 1994 & 1995 & 1996 & 1998 & Overall \\
\hline $\begin{array}{l}\text { Spot Price of European Brent Crude Oil } \\
\text { (1998 US\$ Per Barrel) }\end{array}$ & $\$ 18.56$ & $\$ 17.34$ & $\$ 24.46$ & $\$ 11.63$ & $\$ 17.99$ \\
\hline $\begin{array}{l}\text { Real Ruble-Dollar Exchange Rate } \\
\text { (Real Rubles Per Real US\$) }\end{array}$ & 17.02 & 10.25 & 9.92 & 16.53 & 13.43 \\
\hline $\begin{array}{l}\text { Average Wages Owed to Workers } \\
\text { (\% of Total Wages in the Prior Month) }\end{array}$ & $20 \%$ & $23 \%$ & $36 \%$ & $34 \%$ & $28 \%$ \\
\hline $\begin{array}{l}\text { Average Real Monthly Elderly Pension } \\
\text { (1998 Moscow City Rubles) }\end{array}$ & 741 & 593 & 558 & 535 & 607 \\
\hline $\begin{array}{l}\text { B) The Distribution of Economic Shocks } \\
\text { Across Communities }\end{array}$ & Mean & $\begin{array}{l}\text { Standard } \\
\text { Deviation }\end{array}$ & $\begin{array}{c}25^{\text {th }} \\
\text { Percentile }\end{array}$ & Median & $\begin{array}{c}75^{\text {th }} \\
\text { Percentile }\end{array}$ \\
\hline $\begin{array}{l}\text { Fuel Production in } 1998 \\
\text { (\% of Total Industrial Production) }\end{array}$ & $12.4 \%$ & $19.9 \%$ & $0.1 \%$ & $4.8 \%$ & $14.6 \%$ \\
\hline $\begin{array}{l}\text { Total Trade Per Capita in } 1998 \\
\text { (1998 US\$ Value of Imports Plus Exports) }\end{array}$ & $\$ 0.63$ & $\$ 1.03$ & $\$ 0.13$ & $\$ 0.35$ & $\$ 0.57$ \\
\hline $\begin{array}{l}\text { Average Wages Owed to Workers } \\
\text { (\% of Total Wages in the Prior Month) }\end{array}$ & $28 \%$ & $10 \%$ & $19 \%$ & $28 \%$ & $35 \%$ \\
\hline $\begin{array}{l}\text { Average Real Monthly Elderly Pension } \\
\text { (1998 Moscow City Rubles) }\end{array}$ & 607 & 74 & 547 & 602 & 646 \\
\hline
\end{tabular}




\section{William Davidson Institute Working Paper 412}

Table 4: First-Stage Household Fixed Effects Estimates of the Effect of Different Economic Shocks on Household Income

\begin{tabular}{|c|c|c|c|}
\hline $\begin{array}{l}\text { Dependent Variable: Log Household Income } \\
\left(\mathrm{N}^{*} \mathrm{~T}=7,774 \mid \mathrm{N}=2,335\right)\end{array}$ & $\begin{array}{l}\text { No Year Fixed } \\
\text { Effects }\end{array}$ & Year Fixed Effects & $\begin{array}{l}\text { Region - Year } \\
\text { Fixed Effects }\end{array}$ \\
\hline \multicolumn{4}{|c|}{ A) Log Real US\$ Spot Price of Brent Crude Oil - Coefficient Estimates (Standard Errors) } \\
\hline Main Effect & $\begin{array}{l}0.175^{*} \\
(0.048)\end{array}$ & & \\
\hline Interacted w/ \% Fuel Production in the Community & $\begin{array}{l}0.396 * \\
(0.191)\end{array}$ & $\begin{array}{l}0.431 * \\
(0.191)\end{array}$ & $\begin{array}{l}-0.145 \\
(0.314)\end{array}$ \\
\hline Joint Significance Test of the Instruments [P-Value] & {$[0.000]$} & NA & NA \\
\hline Within R-Squared & 0.05 & 0.06 & 0.07 \\
\hline \multicolumn{4}{|c|}{ B) Log Real Ruble-Dollar Exchange Rate - Coefficient Estimates (Standard Errors) } \\
\hline Main Effect & $\begin{array}{l}-0.145^{*} \\
(0.053)\end{array}$ & & \\
\hline Interacted w/ Log Trade Per Capita in the Community & $\begin{array}{l}-0.109 * \\
(0.035)\end{array}$ & $\begin{array}{l}-0.107 * \\
(0.037)\end{array}$ & $\begin{array}{l}-0.073^{+} \\
(0.044)\end{array}$ \\
\hline Joint Significance Test of the Instruments [P-Value] & {$[0.005]$} & NA & NA \\
\hline Within R-Squared & 0.05 & 0.06 & 0.07 \\
\hline \multicolumn{4}{|c|}{ C) Average \% of Wages Owed to Workers in the Community - Coefficient Estimates (Standard Errors) } \\
\hline Main Effect & $\begin{array}{l}-0.951 * \\
(0.151)\end{array}$ & $\begin{array}{l}-1.311 * \\
(0.223)\end{array}$ & $\begin{array}{l}-1.523^{*} \\
(0.262)\end{array}$ \\
\hline Within R-Squared & 0.05 & 0.06 & 0.07 \\
\hline \multicolumn{4}{|c|}{ D) Average Log Real Monthly Elderly Pension in the Community - Coefficient Estimates (Standard Errors) } \\
\hline Main Effect & $\begin{array}{l}0.072 * \\
(0.012)\end{array}$ & $\begin{array}{l}0.093 * \\
(0.014)\end{array}$ & $\begin{array}{l}0.103 * \\
(0.016)\end{array}$ \\
\hline Within R-Squared & 0.05 & 0.06 & 0.07 \\
\hline \multicolumn{4}{|c|}{ E) All Economic Shocks - Coefficient Estimates (Standard Errors) } \\
\hline Main Effect - Log Real US\$ Spot Price of Brent Crude Oil & $\begin{array}{l}0.343^{*} \\
(0.060)\end{array}$ & & \\
\hline Interacted w/ \% Fuel Production in the Community & $\begin{array}{c}0.243 \\
(0.197)\end{array}$ & $\begin{array}{c}0.315 \\
(0.198)\end{array}$ & $\begin{array}{c}-0.396 \\
(0.339)\end{array}$ \\
\hline Main Effect - Log Real Ruble-Dollar Exchange Rate & $\begin{array}{c}0.075 \\
(0.064)\end{array}$ & & \\
\hline Interacted w/ Log Trade Per Capita in the Community & $\begin{array}{c}-0.032 \\
(0.037)\end{array}$ & $\begin{array}{c}0.001 \\
(0.040)\end{array}$ & $\begin{array}{c}-0.007 \\
(0.049)\end{array}$ \\
\hline Main Effect - Avg. \% of Wages Owed in the Community & $\begin{array}{c}-0.623 * \\
(0.176)\end{array}$ & $\begin{array}{c}-0.985^{*} \\
(0.235)\end{array}$ & $\begin{array}{c}-0.990 * \\
(0.283)\end{array}$ \\
\hline Main Effect - Avg. Log Elderly Pension in the Community & $\begin{array}{l}0.062 * \\
(0.015)\end{array}$ & $\begin{array}{c}0.071 * \\
(0.016)\end{array}$ & $\begin{array}{l}0.086 * \\
(0.018)\end{array}$ \\
\hline Joint Significance Test of the Instruments [P-Value] & [0.000] & [0.000] & {$[0.000]$} \\
\hline Within R-Squared & 0.06 & 0.07 & 0.08 \\
\hline
\end{tabular}




\section{William Davidson Institute Working Paper 412}

Table 5: Household Fixed Effects-Instrumental Variables Estimates of the Response of Household Consumption to Exogenous Changes in Income

\begin{tabular}{|c|c|c|c|}
\hline Dependent Variable $(\mathrm{N} * \mathrm{~T}=7,774 \mid \mathrm{N}=2,335)$ & $\begin{array}{c}\text { No Year Fixed } \\
\text { Effects }\end{array}$ & Year Fixed Effects & $\begin{array}{l}\text { Region - Year } \\
\text { Fixed Effects }\end{array}$ \\
\hline \multicolumn{4}{|c|}{ A) Log Household Income Is Not Instrumented - Coefficient Estimates (Standard Errors) } \\
\hline \multirow[t]{2}{*}{ (1) Log Food Expenditure } & $0.180 *$ & $0.166^{*}$ & $0.163 *$ \\
\hline & $(0.010)$ & $(0.010)$ & $(0.010)$ \\
\hline \multirow[t]{2}{*}{ (2) Log Non-Durable Expenditure } & $0.197^{*}$ & $0.185^{*}$ & $0.182 *$ \\
\hline & $(0.010)$ & $(0.009)$ & $(0.009)$ \\
\hline \multicolumn{4}{|c|}{ B) Log Household Income Is Instrumented w/ Oil Price Shocks - Coefficient Estimates (Standard Errors) } \\
\hline \multirow[t]{2}{*}{ (1) Log Food Expenditure } & $1.584 *$ & $1.017^{*}$ & $1.139 *$ \\
\hline & $(0.273)$ & $(0.260)$ & $(0.369)$ \\
\hline Overidentification Test of the Instruments [P-Value] & [0.169] & NA & NA \\
\hline \multirow[t]{2}{*}{ (2) Log Non-Durable Expenditure } & $1.514^{*}$ & $0.835^{*}$ & $0.957 *$ \\
\hline & $(0.254)$ & $(0.217)$ & $(0.310)$ \\
\hline Overidentification Test of the Instruments [P-Value] & [0.082] & NA & NA \\
\hline
\end{tabular}

C) Log Household Income Is Instrumented w/ Exchange Rate Shocks - Coefficient Estimates (Standard Errors)
(1) Log Food Expenditure
$1.070^{*}$
$0.825^{*}$
$1.229^{*}$

Overidentification Test of the Instruments [P-Value]

$(0.361)$

[0.000]

$(0.308)$

$1.407 *$

NA

$(0.549)$

(2) Log Non-Durable Expenditure

$(0.429)$

$1.143 *$

NA

[0.000]

(0.363)

$1.517 *$

Overidentification Test of the Instruments [P-Value]

NA

$(0.632)$

D) Log Household Income Is Instrumented w/ Wage Arrear Shocks - Coefficient Estimates (Standard Errors)

(1) Log Food Expenditure

$1.356^{*}$

$(0.224)$

$0.711^{*}$

$1.079^{*}$

$(0.159)$

$0.675^{*}$

(2) Log Non-Durable Expenditure

$(0.180)$

$0.724^{*}$

$(0.158)$

$(0.149)$

$0.654 *$

E) Log Household Income Is Instrumented w/ Elderly Pension Shocks - Coefficient Estimates (Standard Errors)

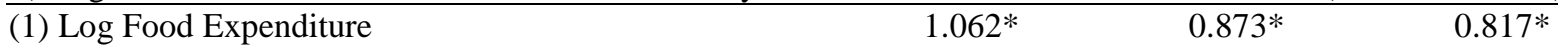

(2) Log Non-Durable Expenditure

$(0.197)$

$(0.161)$

$(0.160)$

$0.902 *$

$0.909^{*}$

$0.834 *$

$(0.167)$

(0.156)

$(0.152)$

F) Log Household Income Is Instrumented w/ All Economic Shocks - Coefficient Estimates (Standard Errors)

(1) Log Food Expenditure

Overidentification Test of the Instruments [P-Value]

(2) Log Non-Durable Expenditure

Overidentification Test of the Instruments [P-Value]
$1.312^{*}$

(0.131)

[0.010]

1.177 *

(0.115)

[0.002]

0.801*

(0.118)

[0.739]

0.780 *

(0.109)

[0.337]
$0.785^{*}$

(0.124)

[0.644]

$0.755^{*}$

(0.113)

[0.272]

Note: Coefficients followed by $*\left({ }^{+}\right)$are significantly different from zero at the $5(10)$ percent level. All regressions also control for the number of male and female household members in eleven age groups, and the number of male and female adults who are married, who have completed general secondary education, who have a specialized secondary, institute / university, and/or professional course diploma, and include household fixed effects. 


\section{William Davidson Institute Working Paper 412}

Table 6: Instrumental Variables Estimates of the Response of Household Consumption to Past, Current, and Future Changes in Income

\begin{tabular}{lcc}
\hline $\begin{array}{l}\text { Dependent Variable }(\mathrm{N} * \mathrm{~T}=2,964 \mid \mathrm{N}=1,700) \\
\text { A) Current and Past Change in Log Hse. Inc. Are Instrumented w/ All Economic Shocks }- \text { Coef. Estimates (SEs) }\end{array}$ \\
\hline Change in Log Total Household Income & $0.621^{*}$ & $0.529^{*}$ \\
& $(0.133)$ & $(0.119)$ \\
Change in Log Total Household Income - Last Round & 0.063 & -0.009 \\
& $(0.145)$ & $(0.130)$ \\
\hline B) Current and Future Change in Log Hse. Inc Are Instrumented w/ All Economic Shocks - Coef. Estimates (SEs) \\
\hline Change in Log Total Household Income & $0.684^{*}$ & $0.792^{*}$ \\
& $(0.160)$ & $(0.144)$ \\
Change in Log Total Household Income - Next Round & -0.109 & 0.116 \\
& $(0.149)$ & $(0.135)$ \\
\hline
\end{tabular}

Note: Coefficients followed by $*\left(^{+}\right)$are significantly different from zero at the 5 (10) percent level. All regressions also control for changes in the number of male and female household members in eleven age groups, and the number of male and female adults who are married, who have completed general secondary education, who have a specialized secondary, institute / university, and/or professional course diploma, and include year fixed effects. Both current and past (future) changes in economic shocks are used to instrument for current and past (future) changes in income. 


\section{William Davidson Institute Working Paper 412}

Table 7: OLS Estimates of the Effect of Household Savings on Future Changes in Income

\begin{tabular}{lcc}
\hline Dependent Variable - Coefficient Estimates (SEs) & $\begin{array}{c}\text { Change in Income } \\
\text { Next Round }\end{array}$ & $\begin{array}{c}\text { Change in Income } \\
\text { Two Rounds Ahead }\end{array}$ \\
\hline A) Net Savings (Financial and Durable Good) & $0.133^{*}$ & -0.013 \\
& $(0.017)$ & $(0.021)$ \\
\# Observations & 5226 & 2964 \\
\# Households & 2262 & 1700 \\
\hline B) Change in Net Savings (Financial and Durable Good) & $0.067^{*}$ & -0.010 \\
\# Observations & $(0.016)$ & $(0.024)$ \\
\# Households & 2964 & 1264 \\
\hline
\end{tabular}

Note: Coefficients followed by $*\left({ }^{+}\right)$are significantly different from zero at the 5 (10) percent level. All regressions also control for (in panel B, changes in) the number of male and female household members in eleven age groups, and the number of male and female adults who are married, who have completed general secondary education, who have a specialized secondary, institute / university, and/or professional course diploma, and include year fixed effects. 


\section{William Davidson Institute Working Paper 412}

Table 8: Household FE-IV Estimates of the Response of Household Consumption and Savings to Exogenous Changes in Income Interacted With First Year Non-Financial Assets

\begin{tabular}{|c|c|c|c|}
\hline Dependent Variable $(\mathrm{N} * \mathrm{~T}=4,996 \mid \mathrm{N}=1,860)$ & $\begin{array}{l}\text { Log Food } \\
\text { Expenditure }\end{array}$ & $\begin{array}{l}\text { Log Non-Durable } \\
\text { Expenditure }\end{array}$ & Net Savings \\
\hline \multicolumn{4}{|c|}{ Log Household Income Is Instrumented w/ All Economic Shocks - Coefficient Estimates (Standard Errors) } \\
\hline Main Effect - Log Total Household Income & $\begin{array}{l}0.456^{*} \\
(0.110)\end{array}$ & $\begin{array}{c}0.453^{*} \\
(0.102)\end{array}$ & $\begin{array}{l}-0.430 \\
(0.269)\end{array}$ \\
\hline Interacted w/ Medium Group Non-Financial Assets & $\begin{array}{l}-0.027 \\
(0.165)\end{array}$ & $\begin{array}{l}-0.032 \\
(0.154)\end{array}$ & $\begin{array}{c}0.202 \\
(0.315)\end{array}$ \\
\hline Interacted w/ High Group Non-Financial Assets & $\begin{array}{l}-0.051 \\
(0.168)\end{array}$ & $\begin{array}{l}0.048 \\
(0.157)\end{array}$ & $\begin{array}{c}0.174 \\
(0.296)\end{array}$ \\
\hline Overidentification Test of the Instruments [P-Value] & [0.001] & {$[0.012]$} & {$[0.000]$} \\
\hline
\end{tabular}


William Davidson Institute Working Paper 412

Seasonally Adjusted RGDP

\$ / Ruble Exchange Rate

$\ldots \ldots$ B $\ldots \ldots$ Brent Crude Oil Price

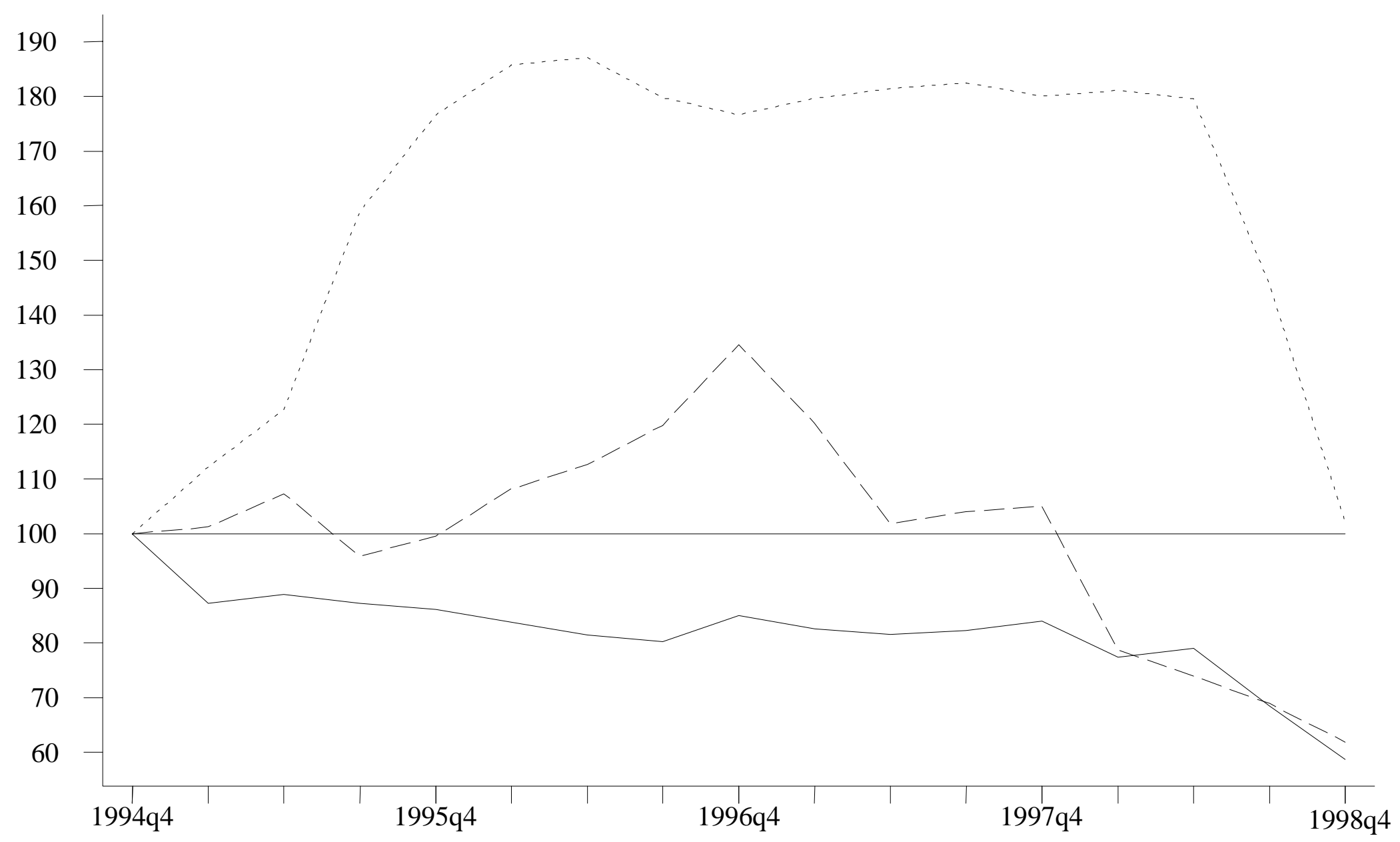

Figure 1: Quarterly Index (4th Quarter $1994=100$ ) 
William Davidson Institute Working Paper 412
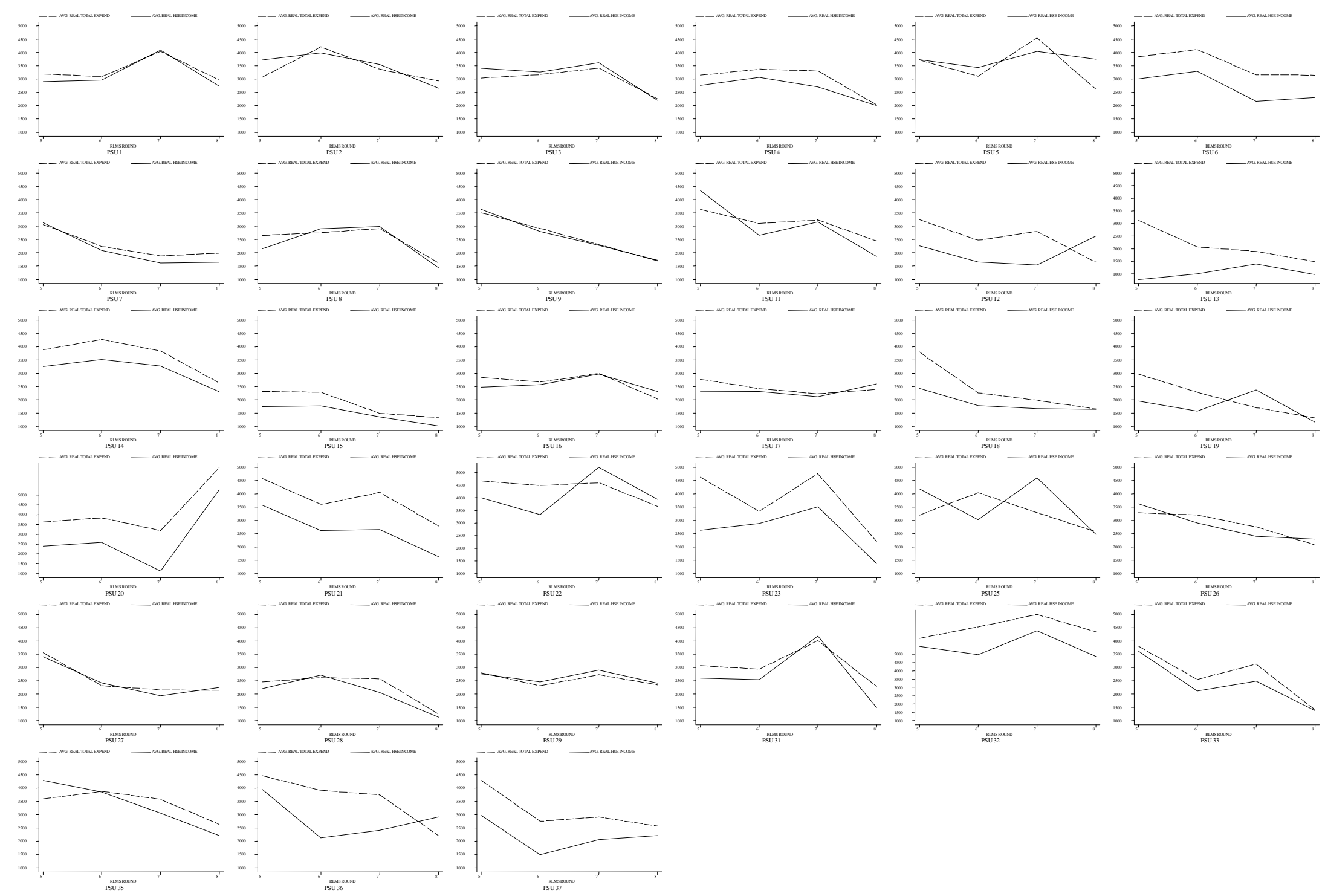

Figure 2: Household Income and Expenditure By Community 


\section{DAVIDSON INSTITUTE WORKING PAPER SERIES - Most Recent Papers}

The entire Working Paper Series may be downloaded free of charge at: www.wdi.bus.umich.edu

CURRENT AS OF 11/30/01

\begin{tabular}{|c|c|c|}
\hline Publication & Authors & Date \\
\hline $\begin{array}{l}\text { No. 412: The Response of Consumption in Russian Households to } \\
\text { Economic Shocks }\end{array}$ & Steven Stillman & Oct. 2001 \\
\hline No. 411: Mark-ups in Hungarian Corporate Sector & László Halpern and Gábor Körösi & Aug. 2001 \\
\hline No. 410: Economic Development, Legality, and the Transplant Effect & $\begin{array}{l}\text { Daniel Berkowitz, Katarina } \\
\text { Pistor, Jean-Francois Richard }\end{array}$ & Sept. 2001 \\
\hline No. 409: Development Strategy, Viability, and Economic Convergence & Justin Yifu Lin & Oct. 2001 \\
\hline No. 408: Labor Supply, Informal Economy and Russian Transition & Maxim Bouev & May 2001 \\
\hline No. 407: Corporate Governance in China: Then and Now & Cindy Schipani and Liu Junhai & Nov. 2001 \\
\hline No. 406: Entrepreneurship and Post-Socialist Growth & $\begin{array}{l}\text { Daniel Berkowitz and David N. } \\
\text { DeJong }\end{array}$ & Oct. 2001 \\
\hline $\begin{array}{l}\text { No. } 405 \text { Forthcoming in: European Economic Review, "Policy Reform } \\
\text { and Growth in Post-Soviet Russia." }\end{array}$ & $\begin{array}{l}\text { Daniel Berkowitz and David N. } \\
\text { DeJong }\end{array}$ & Oct. 2001 \\
\hline $\begin{array}{l}\text { No. 404: Social Policies and Structures: Institutional Frictions and Traps } \\
\text { in the Czech Republic after } 1989\end{array}$ & Jiří Večerník & Nov. 2001 \\
\hline $\begin{array}{l}\text { No. 403: Investment, Efficiency, and Credit Rationing: Evidence from } \\
\text { Hungarian Panel Data }\end{array}$ & Mathilde Maurel & Nov. 2001 \\
\hline $\begin{array}{l}\text { No. 402: Subduing High Inflation in Romania. How to Better Monetary } \\
\text { and Exchange Rate Mechanisms? }\end{array}$ & $\begin{array}{l}\text { Daniel Daianu and Radu } \\
\text { Vranceanu }\end{array}$ & Aug. 2001 \\
\hline $\begin{array}{l}\text { No. 401: The Gender Wage Gap in Bulgaria: A Semiparametric } \\
\text { Estimation of Discrimination }\end{array}$ & Dean Jolliffe & July 2001 \\
\hline $\begin{array}{l}\text { No. 400: Do External Auditors Perform a Corporate Governance Role in } \\
\text { Emerging Markets? Evidence from East Asia }\end{array}$ & Joseph P. H. Fan and T.J. Wong & Oct. 2001 \\
\hline $\begin{array}{l}\text { No. 399: Financial Conditions and Investment during the Transition: } \\
\text { Evidence from Czech Firms }\end{array}$ & Lubomír Lízal and Jan Svejnar & Oct. 2001 \\
\hline $\begin{array}{l}\text { No. 398: Accessible Pareto-Improvements: Using Market Information to } \\
\text { Reform Inefficiencies }\end{array}$ & Michael Mandler & May 2001 \\
\hline No. 397: The Making of an Integrated National Grain Market in China & iao Zhou & Oct. 2001 \\
\hline No. 396: Corruption and Resource Allocation: Evidence from China & & June 2001 \\
\hline $\begin{array}{l}\text { No. 395: Government Shareholding and the Value of China's Modern } \\
\text { Firms }\end{array}$ & Lihui Tian & Apr. 2001 \\
\hline No. 394: Labor Hoarding in Russia: Where Does it Come from? & $\begin{array}{l}\text { Rouslan Koumakhov and Boris } \\
\text { Najman }\end{array}$ & June 2000 \\
\hline $\begin{array}{l}\text { No. 393: Ownership Structure, Corporate Governance, And Firm Value: } \\
\text { Evidence from the East Asian Financial Crisis }\end{array}$ & Michael Lemmon and Karl Lins & Apr. 2001 \\
\hline No. 392: Marshall and Labour Demand in Russia: Going Back to Basics & $\begin{array}{l}\text { Jozef Konings and Hartmut } \\
\text { Lehmann }\end{array}$ & Aug. 2001 \\
\hline No. 391: Economic Transition and Elections in Poland & $\begin{array}{l}\text { John E. Jackson, Jacek Klich, and } \\
\text { Krystyna Poznańska }\end{array}$ & June 2001 \\
\hline $\begin{array}{l}\text { No. 390: Effects of Bank Insolvency and Strategic Uncertainty on } \\
\text { Corporate Restructuring in Transition Economies }\end{array}$ & Christa Hainz & Aug. 2001 \\
\hline No. 389: Mark-Up Pricing In Bulgarian Manufacturing & $\begin{array}{l}\text { Rumen Dobrinsky, Boyko } \\
\text { Nikolov, and Nikolay Markov }\end{array}$ & June 2001 \\
\hline $\begin{array}{l}\text { No. 388: Globalization and Firms' Financing Choices: } \\
\text { Evidence from Emerging Economies }\end{array}$ & $\begin{array}{l}\text { Sergio Schmukler and Esteban } \\
\text { Vesperoni }\end{array}$ & May 2001 \\
\hline $\begin{array}{l}\text { No. 387: The Distributional Impacts of Indonesia's Financial Crisis on } \\
\text { Household Welfare: A "Rapid Response" Methodology }\end{array}$ & $\begin{array}{l}\text { Jed Friedman and James } \\
\text { Levinsohn }\end{array}$ & Sept. 2001 \\
\hline $\begin{array}{l}\text { No. 386a: Corporate Financial Policies and Performance Around } \\
\text { Currency Crises }\end{array}$ & $\begin{array}{l}\text { Arturo Bris, Yrjö Koskinen, and } \\
\text { Vicente Pons }\end{array}$ & Oct. 2001 \\
\hline No. 385: Ownership and Productive Efficiency: Evidence from Estonia & Derek C. Jones and Niels Mygind & Aug. 2001 \\
\hline
\end{tabular}

